\title{
Coastal upwelling is linked to temporal genetic variability in the acorn barnacle Balanus glandula
}

\author{
D. J. Barshis ${ }^{1, *}$, E. E. Sotka ${ }^{1}$, R. P. Kelly ${ }^{1}$, A. Sivasundar ${ }^{1}$, B. A. Menge ${ }^{2}$, J. A. Barth ${ }^{3}$, \\ S. R. Palumbi ${ }^{1}$
}

${ }^{1}$ Hopkins Marine Station, Stanford University, Pacific Grove, California 93950, USA

${ }^{2}$ Department of Zoology and ${ }^{3}$ College of Oceanic \& Atmospheric Sciences, Oregon State University, Corvallis, Oregon 97331 , USA

\begin{abstract}
Dispersal and recruitment are central processes that shape the geographic and temporal distributions of populations of marine organisms. However, significant variability in factors such as reproductive output, larval transport, survival, and settlement success can alter the genetic identity of recruits from year to year. We designed a temporal and spatial sampling protocol to test for genetic heterogeneity among adults and recruits from multiple time points along a $\sim 400 \mathrm{~km}$ stretch of the Oregon (USA) coastline. In total, 2824 adult and recruiting Balanus glandula were sampled between 2001 and 2008 from 9 sites spanning the Oregon coast. Consistent with previous studies, we observed high mitochondrial DNA diversity at the cytochrome oxidase I locus (884 unique haplotypes) and little to no spatial genetic population structure among the 9 sites $\left(\Phi_{\mathrm{ST}}=0.00026, \mathrm{p}=0.170\right)$. However, subtle but significant temporal shifts in genetic composition were observed among year classes $\left(\Phi_{\mathrm{ST}}=0.00071, \mathrm{p}=0.035\right)$, and spatial $\Phi_{\mathrm{ST}}$ varied from year to year. These temporal shifts in genetic structure were correlated with yearly differences in the strength of coastal upwelling $(\mathrm{p}=0.002)$, with greater population structure observed in years with weaker upwelling. Higher levels of barnacle settlement were also observed in years with weaker upwelling $(p<0.001)$. These data suggest the hypothesis that low upwelling intensity maintains more local larvae close to shore, thereby shaping the genetic structure and settlement rate of recruitment year classes.
\end{abstract}

KEY WORDS: Balanus glandula - Upwelling - Reproductive sweepstakes - Temporal genetic change $\cdot$ Recruitment $\cdot$ Local oceanography

\section{INTRODUCTION}

The degree to which populations of organisms are geographically structured is fundamental to our understanding of biodiversity, evolution, and conservation. Genetic drift, natural selection, and mutation are among the forces that can differentiate populations across space on the scale of meters to as much as thousands of kilometers (Dobzhansky 1982, Coyne \& Orr 2004). However, while much attention has focused on the spatial structure of populations, an increasing body of work suggests that population structure can often change over time, with shifts in the genetic composition of year classes among different generations (e.g. Hedgecock 1994a, Johnson \& Wernham 1999, Chapman et al. 2002, Dannewitz et al. 2005).

Signatures of temporal genetic change have been found in many populations of marine species with a variety of dispersal capabilities, pelagic larval durations, and reproductive outputs from vertebrates (e.g. Lundy et al. 2000, Chapman et al. 2002, Lenfant \& Planes 2002, Planes \& Lenfant 2002, McPherson et al. 2003, Dannewitz et al. 2005, Burford \& Larson 2007, 
Liu \& Ely 2009, Christie et al. 2010) to invertebrates (e.g. Colgan 1981, Hedgecock 1994b, David et al. 1997, Li \& Hedgecock 1998, Johnson \& Wernham 1999, Moberg \& Burton 2000, Hedgecock et al. 2007, Toonen \& Grosberg in press). However, temporal genetic variation is inconsistent in nature, and many studies of similar species, even conspecifics, have not detected the same telltale signs of genetic variability over time (e.g. Lessios et al. 1994, De Wolf et al. 1998, Gold et al. 1999, Gilg \& Hilbish 2003, Lambert et al. 2003, Diaz-Jaimes et al. 2006, Calderón et al. 2009)

A variety of mechanisms have been proposed as potential causes for genetic variation over time, including ocean currents, variability in reproductive output, differential settlement success, variability in larval behavior, post-spawning mortality, genetic drift, and natural selection (e.g. Colgan 1981, Johnson \& Black 1982, 1984, Hedgecock 1994a, Lundy et al. 2000, Chapman et al. 2002). In particular, many researchers have suggested that coastal oceanography plays a strong role in shaping the abundance of successfully recruiting individuals of marine species (e.g. Roughgarden et al. 1988, Alexander \& Roughgarden 1996, Menge 2000, Shanks \& Brink 2005). However, research assessing the relative influence of these forces on genetic variability is sparse, and the link between near-shore oceanography and temporal shifts in gene frequencies has seldom been investigated.

\section{Coastal upwelling dynamics}

The west coast of the continental USA is characterized by the presence of seasonal upwelling that varies on multiple temporal scales, from intra-seasonally to inter-seasonally to annually to decadally. Upwelling is an oceanographic process that, by inducing both cross-shelf and alongshore currents, is likely to affect larval dispersal. Areas of strong seasonal upwelling are found along coastlines across the globe (e.g. Alexander \& Roughgarden 1996, Poulin et al. 2002, Weissberger \& Grassle 2003), but the degree to which upwelling shapes patterns of recruitment and larval transport of intertidal invertebrate communities is not fully understood. Many studies have suggested that during periods of strong upwelling, increased offshore flow transports larvae far out to sea, reducing settlement and exerting restrictive influence on the composition of coastal communities (e.g. Roughgarden et al. 1988, Farrell et al. 1991, Alexander \& Roughgarden 1996, Escribano \& Hidalgo 2000, Connolly et al. 2001). Conversely, upwelling relaxation events can reduce and reverse offshore larval transport, promoting increased settlement and abundance of barnacles and other intertidal species (e.g. Farrell et al. 1991, Wing et al. 1995, Weissberger \& Grassle 2003, Dudas et al. 2009).

Despite this work, other studies have found weaker correlations between upwelling and recruitment, suggesting that other factors such as larval swimming behavior, internal waves, and vertical migration may be driving observed changes in abundances of larvae and successful recruits (e.g. Poulin et al. 2002, Lagos et al. 2005, Shanks \& Brink 2005, Shanks \& Pfister 2009, Shanks \& Shearman 2009). Recent studies along the California coastline (Morgan et al. 2009a,b, Morgan \& Fisher 2010) highlight the complicated array of oceanographic and biological factors that may influence patterns of larval recruitment in this region. While the relative importance of each specific factor remains a topic of much debate, it is clear that a wide variety of oceanographic processes contributes to variability in larval recruitment on both short- and long-term timescales.

\section{Balanus glandula in the California Current System}

The high abundance, life history characteristics, and broad dispersal of the acorn barnacle Balanus glandula provide an excellent system in which to study the relative influence of potential forces that shape the genetic composition of sequential year classes. B. glandula is found along the west coast of North America from Baja California to the Aleutian Islands (Newman \& Abbott 1980), and can occur at densities as great as $30000 \mathrm{~m}^{-2}$ (Menge 2000). Reproductively mature $B$. glandula adults produce 2 to 6 broods per year and release up to 30000 nauplius larvae per brood (Newman \& Abbott 1980). These larvae must feed in the water column for at least $2 \mathrm{wk}$ prior to transformation into cyprid larvae and eventual settlement (Brown \& Roughgarden 1985). Although the specific relationship between pelagic larval duration and dispersal potential is complex (e.g. Shanks 2009), the $\sim 2$ wk planktonic larval stage may make $B$. glandula offspring subject to high levels of dispersal via the prevailing currents in the region, while the output of thousands of well developed larvae could create the potential for high variance in settlement success.

Indeed, past studies of population connectivity in Balanus glandula identified high genetic similarity between populations across the species range and notable levels of unexplained microgeographic ge- 
netic heterogeneity (Hedgecock 1982, 1986, 1994b). In addition, more recent research with increased spatial sampling revealed strong regional differences in B. glandula population structure between the California and Oregon coastlines (Wares et al. 2001, Sotka et al. 2004, Galindo et al. 2010). Sotka et al. (2004) discovered steep genetic clines along the California coastline, in contrast to relatively little population structure in Oregon. This was mirrored closely by geographic trajectories of oceanographic drifters, suggesting a relationship between regional oceanographic current patterns and geographic patterns of gene flow among B. glandula populations (Sotka et al. 2004). While available evidence for the Oregon coastline points towards little spatial genetic structuring overall, ecologically important questions remain as to whether patterns of genetic diversity in B. glandula populations are temporally stable, and to what degree previously observed microgeographic genetic variability (Hedgecock 1982, 1986) may be explained by local oceanographic processes.

We examined spatio-temporal genetic structure in acorn barnacles across 9 sites spanning the Oregon coastline, an area with high barnacle abundance, low genetic structure, and moderate upwelling. The 2 main goals of this study were to examine the spatial and temporal genetic composition of adult and juvenile Balanus glandula populations in Oregon and to explore potential relationships between local oceanography and patterns of genetic diversity among populations and year classes of recruits.

\section{MATERIALS AND METHODS}

\section{Adult genetic sample collection}

Adult Balanus glandula were collected from 9 sites spanning the Oregon coastline (Fig. 1, Table 1) in July 2001 and 2003. These sites are similarly characterized by large natural rock surfaces and boulders (excepting the artificially constructed Newport Jetty), west-facing orientation, and high wave exposure, which are features common to the Oregon rocky inter-tidal. At each site, approximately 50 B. glandula adults from each population were collected haphazardly from the upper edge of the Mytilus spp. mussel zone (+1.8 to 2.3 m mean low low water) and stored immediately in 70-95\% ethanol. Because the 2003 adults were sampled from marked substratum that had been physically cleared in July 2001, the 2003 and 2001 adults represent nonoverlapping cohorts.

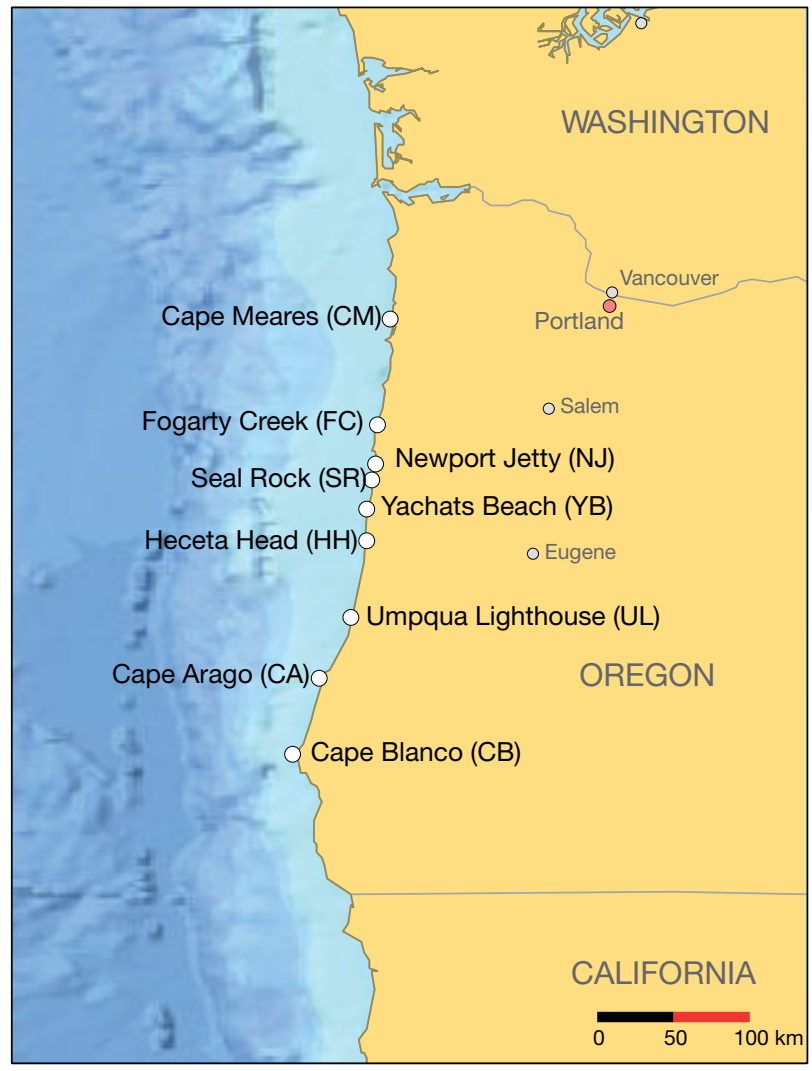

Fig. 1. Nine sampling locations along the Oregon (USA) coastline. Specific location and sampling information provided in Table 1. Map created using www.planiglobe.com

\section{Recruit genetic sample collection}

Larval recruits of Balanus glandula were collected from the same 9 sites at various times between 2001 and 2008 (Table 1). In 2001, recruits were sampled weekly for 9 wk starting on 17 July and ending on 19 September. Subsequently, during the period from 2004 to 2008, new settlement plates were placed in the field each spring (April), and recruits were only sampled once annually in the late fall (mid-September to October, depending on the year). The majority of yearly settlement for B. glandula typically occurs during July to November (Menge 2000, Barth et al. 2007, Broitman et al. 2008); thus only the 2001 recruit samples and the fall (September/October) samples from 2004 to 2008 were used for genetic analysis of settlers. Larval recruits for genetic analysis were collected on plexiglass plates $(10 \times 10 \times 0.6 \mathrm{~cm})$ covered with a rough-textured rubber surface (Safety-Walk, $3 \mathrm{M}$ ) that enhances larval attachment (Farrell et al. 1991, Menge et al. 1999, 2010). The plates were attached to the rock surface within $\sim 10 \mathrm{~m}$ of the col- 
Table 1. Balanus glandula. Location names and number of individuals sampled in each year of the genetics study. A: adults; S: settlers; M: mixed settlers and adults

\begin{tabular}{|c|c|c|c|c|c|c|c|c|c|c|c|}
\hline Location & Latitude (N) & Longitude (W) & $2001 \mathrm{~A}$ & $2001 \mathrm{~S}$ & $2003 \mathrm{M}$ & $2004 \mathrm{~S}$ & $2005 \mathrm{~S}$ & $2006 \mathrm{~S}$ & $2007 \mathrm{~S}$ & $2008 \mathrm{~S}$ & Total \\
\hline Cape Meares (CM) & 45.4728 & 123.9689 & 37 & 41 & 37 & 40 & 40 & 14 & 47 & 43 & 299 \\
\hline Fogarty Creek (FC) & 44.8359 & 124.0591 & 42 & 37 & 31 & 30 & 31 & 20 & 40 & 45 & 276 \\
\hline Newport Jetty (NJ) & 44.6114 & 124.0748 & 40 & 75 & 34 & 38 & 33 & 28 & 32 & 42 & 322 \\
\hline Seal Rock (SR) & 44.4994 & 124.0845 & 36 & 88 & 32 & 18 & 46 & 22 & 46 & 43 & 331 \\
\hline Yachats Beach (YB) & 44.3180 & 124.1089 & 40 & 137 & 35 & 44 & 43 & 19 & 18 & 48 & 384 \\
\hline Heceta Head (HH) & 44.1343 & 124.1235 & 37 & 116 & 33 & 14 & 33 & 21 & 19 & 48 & 321 \\
\hline Umpqua Lighthouse (UL) & 43.6669 & 124.2091 & 37 & 47 & 33 & 37 & 30 & 32 & 44 & 45 & 305 \\
\hline Cape Arago (CA) & 43.3067 & 124.4024 & 42 & 46 & 32 & 20 & 36 & 18 & 37 & 44 & 275 \\
\hline \multirow[t]{2}{*}{ Cape Blanco (CB) } & 42.8409 & 124.5647 & 34 & 74 & 38 & 45 & 42 & 22 & 14 & 42 & 311 \\
\hline & & Total & 345 & 661 & 305 & 286 & 334 & 196 & 297 & 400 & 2824 \\
\hline
\end{tabular}

lected adults using a stainless steel screw and a predrilled hole. Plates were replaced during sampling, and the removed Safety-Walk tape and all attached barnacles were placed directly into 70-95\% ethanol. Settlement plates from all sites were collected within $\sim 48 \mathrm{~h}$ of each other during each sampling period.

\section{DNA extraction and sequencing}

Individual settlers were plucked from the SafetyWalk tape, and DNA was extracted and amplified following a previous study (Sotka et al. 2004). Briefly, samples were extracted in 10\% Chelex-100 resin (Bio-Rad Laboratories), and $386 \mathrm{bp}$ of the 3' end of cytochrome oxidase I (COI) were amplified under standard PCR conditions (30 cycles, annealing temperature of $\left.52.2^{\circ} \mathrm{C}\right)$ using the primers BF2 $\left(5^{\prime}\right.$-TGT AAT TGT TAC TGC TCA TGC-3') and BR2 (5'-ACC AAA RAA YCA GAA TAA GTG TTG-3'). Amplifications were sequenced in 1 direction on an ABI Prism 3100 Genetic Analyzer (Applied Biosystems), and sequences were aligned using Sequencher 4.1 (Gene Codes Corporation).

\section{Settlement abundance collections}

For yearly settlement abundance, plates were prepared as above and deployed and collected on a monthly basis between April and October from 2000 to 2008 (Barth et al. 2007, Broitman et al. 2008). Locations were similar to those used in the genetic study, with the exception of 2 additional sites where abundance plates were deployed (Boiler Bay, BB; and Strawberry Hill, SH), and the absence of plates at Newport Jetty (NJ), Heceta Head (HH), and Umpqua
Lighthouse (UL). After collection, the number of Balanus glandula settlers and cyprids was counted using a dissecting microscope. New plates were set out each time old plates were collected.

The settlement counts and recruitment genetics samples represent 2 independently collected data sets; hence the results from each of these data sets are from non-overlapping individuals.

\section{Wind-stress calculations}

To assess potential relationships between barnacle genetic/settlement data and nearshore oceanographic conditions, we compared yearly barnacle genetics from 2004 to 2008 to a measure of cumulative alongshore wind stress for the Oregon coastline from the online database of Pierce \& Barth (2009; http:// damp.coas.oregonstate.edu/windstress/). Owing to the different sampling method employed in 2001, data were analyzed both including as well as excluding these samples. There was no difference in statistical outcome between the 2 analyses and, for clarity, only data from 2004 to 2008 are presented herein. The cumulative wind-stress measurement is a calculation of the accumulated southward wind-stress intensity during the upwelling season and can be used as a proxy of the upwelling strength for a particular year (Pierce et al. 2006, Barth et al. 2007). Specific methods and calculations behind the measurement have been described previously (Pierce et al. 2006, Barth et al. 2007, Pierce \& Barth 2009). A seasonal average rate was calculated for each individual year by dividing the total cumulative wind stress for that year by the number of days between the beginning of upwelling favorable winds (termed the spring transition) and the end of the upwelling season (fall transition), yielding a single average 
intensity for a particular upwelling season. As the upwelling and barnacle settlement seasons are similar year to year, this allowed us to obtain a single value of average upwelling strength for each year that was comparable to the measurements of Balanus glandula genetic composition taken toward the end of each yearly settlement season.

\section{Data analysis}

Standard genetic indices (e.g. nucleotide and haplotype diversity) and a series of genetic structure comparisons using analysis of molecular variance (AMOVA) were calculated in Arlequin 3.0 (Schneider et al. 2000) using a pairwise difference distance matrix. Potential spatial genetic structure was tested with a hierarchical AMOVA examining structure among populations grouped across all sampling years and among populations within each separate year. The potential for temporal changes in genetic structure was similarly assessed with a hierarchical AMOVA examining structure among years grouped across all populations and among years for each individual population (Table 2). Each AMOVA was assessed for significance with 50000 permutations. To examine specific differences between populations, pairwise $\Phi_{\text {ST }}$ calculations (Weir \& Cockerham 1984) were performed between populations within a given year. The average pairwise difference between populations was calculated for each year (2004 to 2008) and used in further correlation analyses.

A non-parametric Kruskal-Wallis test was employed to test whether there were significant differences between sampling points in haplotype diversity, nucleotide diversity, and estimates of $\theta_{S}$ (Watterson 1975). This non-parametric approach was required because of the non-normal and heteroscedastic nature of the data set. To test for associations between diversity indices and upwelling intensity for a particular year, a correlation test was performed between diversity statistics and the average cumulative wind stress for each sampling year. As single-point measurements representing the entire peak settlement period were only taken from 2004 to 2008, correlation analyses comparing settler genetic indices to upwelling intensity were only conducted on these data.

Similarly, correlation analyses were performed between the average between-population pairwise $\Phi_{\mathrm{ST}}$ value for a given year and the average cumulative wind stress for that same year for 2004 to 2008. A non-parametric Kendall's Tau correlation was required for the average across all populations owing to the non-normal and heteroscedastic nature of the data set. All correlation analyses were performed using the free software package R (www.R-project. org).

Table 2. Balanus glandula. Summary of F-statistics (Weir \& Cockerham 1984) based on an analysis of molecular variance calculated in Arlequin ver 3.0. Bold denotes significant p-values. Abbreviations as in Table 1. GenBank accession numbers for all unique sequences generated in this study are JN851869-JN852752. Note, the 2003 samples were taken after multiple years of settlement, hence 'mixed' refers to overlapping cohorts of recent recruits and 1 and 2 yr old 'adults', while 'both' refers to separate sample years combined together

\begin{tabular}{|c|c|c|c|c|c|c|c|}
\hline Analysis & Comparison & $\begin{array}{l}\text { Temporal } \\
\text { or spatial }\end{array}$ & $\begin{array}{l}\text { No. populations } \\
\text { (no. groups) }\end{array}$ & No. ind. & $\begin{array}{l}\text { Adults/ } \\
\text { settlers }\end{array}$ & $F$-statistic & $\mathrm{p}$ \\
\hline \multicolumn{2}{|c|}{1 Among locations grouped by year } & Spatial & $72(9)$ & 2824 & Both & 0.00026 & $0.170 \pm 0.012$ \\
\hline & Temporal & $72(8)$ & 2824 & Both & 0.00071 & $0.035 \pm 0.0056$ \\
\hline \multicolumn{2}{|c|}{$\begin{array}{l}2 \text { Among years grouped by location } \\
3\end{array}$} & Spatial & $9(1)$ & 345 & Adults & -0.0033 & $0.71 \pm 0.014$ \\
\hline \multicolumn{2}{|r|}{2001} & Spatial & 9 (1) & 661 & Settlers & -0.0049 & $0.99 \pm 0.0032$ \\
\hline \multicolumn{2}{|r|}{$\begin{array}{l}2003 \\
2004\end{array}$} & Spatial & $9(1)$ & 305 & Mixed & 0.0026 & $0.30 \pm 0.016$ \\
\hline 6 & 2004 & Spatial & $9(1)$ & 286 & Settlers & 0.014 & $0.023 \pm 0.0054$ \\
\hline \multicolumn{2}{|r|}{2005} & Spatial & $9(1)$ & 334 & Settlers & -0.0055 & $0.88 \pm 0.0090$ \\
\hline \multicolumn{2}{|r|}{2006} & Spatial & $9(1)$ & 196 & Settlers & 0.0047 & $0.26 \pm 0.018$ \\
\hline \multicolumn{2}{|r|}{2007} & Spatial & $9(1)$ & 297 & Settlers & 0.014 & $0.011 \pm 0.0030$ \\
\hline \multicolumn{2}{|r|}{2008} & Spatial & $9(1)$ & 400 & Settlers & -0.00035 & $0.48 \pm 0.017$ \\
\hline \multicolumn{2}{|l|}{$\begin{array}{l}11 \\
12\end{array}$} & Temporal & $8(1)$ & 299 & Both & 0.015 & $0.0088 \pm 0.0032$ \\
\hline \multirow{2}{*}{\multicolumn{2}{|c|}{$\begin{array}{l}12 \\
13\end{array}$}} & Temporal & $8(1)$ & 276 & Both & 0.0033 & $0.27 \pm 0.013$ \\
\hline & & Temporal & $8(1)$ & 322 & Both & -0.0013 & $0.57 \pm 0.016$ \\
\hline \multicolumn{2}{|r|}{$\mathrm{SR}$} & Temporal & $8(1)$ & 331 & Both & -0.002 & $0.65 \pm 0.014$ \\
\hline \multicolumn{2}{|r|}{ YB } & Temporal & $8(1)$ & 384 & Both & -0.0019 & $0.63 \pm 0.018$ \\
\hline \multicolumn{2}{|r|}{$\mathrm{HH}$} & Temporal & $8(1)$ & 321 & Both & -0.0023 & $0.62 \pm 0.016$ \\
\hline \multicolumn{2}{|r|}{ UL } & Temporal & $8(1)$ & 305 & Both & -0.0014 & $0.58 \pm 0.014$ \\
\hline \multicolumn{2}{|r|}{$\mathrm{CA}$} & Temporal & $8(1)$ & 275 & Both & 0.01 & $0.058 \pm 0.0063$ \\
\hline \multicolumn{2}{|r|}{$\mathrm{CB}$} & Temporal & $8(1)$ & 311 & Both & -0.00039 & $0.51 \pm 0.013$ \\
\hline
\end{tabular}


To investigate the strength of an isolation by distance (IBD) association, linearized pairwise $\Phi_{\mathrm{ST}}$ values $\left(\Phi_{\mathrm{ST}} /\left[1-\Phi_{\mathrm{ST}}\right]\right)$ between populations were compared to the geographic distance between those same populations. The IBD approach asks whether more distant populations have a significantly higher chance of showing greater $\Phi_{\mathrm{ST}}$ values than nearby populations (Bohonak 1999). Assuming that the sampling error and measurement noise are independent of geographic separation between populations, an increase in $\Phi_{\mathrm{ST}}$ with distance strongly suggests the action of limited dispersal and may provide a more accurate picture of dispersal distance than traditional F-statistics alone (Palumbi 2003). A Mantel test of correlation between matrices was conducted in the program IBDWS (Jensen et al. 2005).

Where appropriate, correction for multiple testing was performed using the tail-based false discovery rate (FDR) method as described by Strimmer (2008) using the R package 'fdrtool.' Mean values are presented \pm 1 SD unless indicated otherwise.

\section{RESULTS}

\section{Diversity indices}

There was a high degree of polymorphism in the COI locus in Balanus glandula, with 884 unique haplotypes from a total of 2824 sequenced individuals. For all individuals, total haplotype diversity $\left(\mathrm{h}^{2}\right)$ was $0.952 \pm 0.003$, nucleotide diversity was $1.557 \pm$ $0.839 \%$, and $\theta_{S}$ (Watterson 1975) was $17.620 \pm 2.952$. Genetic diversity was high among all samples, and while $\theta_{S}$ was different between individual years ( $\mathrm{p}<0.005)$, no difference in $\mathrm{h}^{2}$ or nucleotide diversity was observed between time points or between populations.

\section{$\Phi_{\text {ST }}$ analyses of spatial and temporal structure}

The AMOVA across all populations suggested no significant spatial genetic structure between populations $\left(\Phi_{\mathrm{ST}}=0.00026, \mathrm{p}=0.170\right.$; Table 2$)$. Among the 288 pairwise comparisons among populations within the same year/year class, 23 (7.9\%) were initially significant at the $5 \%$ level, with 14 (11 of which occurred in 2007) remaining significant at the $<0.05$ level after FDR correction (Strimmer 2008). The AMOVA examining structure among different years revealed significant changes in genetic structure over time $\left(\Phi_{\mathrm{ST}}=0.00071, \mathrm{p}=0.035\right.$; Table 2$)$. Addi- tionally, when tests of spatial genetic structure were performed for each year individually, data for both 2004 and 2007 settlers revealed significant genetic structuring at the between-population level $\left(\Phi_{\mathrm{ST}}=\right.$ $0.014, \mathrm{p}=0.023$ and $\Phi_{\mathrm{ST}}=0.014, \mathrm{p}=0.011$ for 2004 and 2007, respectively; Table 2). On a population-bypopulation level, the Cape Meares (CM) population contained the strongest among-year changes in genetic structure $\left(\Phi_{\mathrm{ST}}=0.015, \mathrm{p}=0.009\right)$. As a whole, the $\Phi_{\mathrm{ST}}$ analyses revealed subtle but significant temporal shifts in the genetic composition of these populations.

No year class had a significant IBD association between genetic distance (linearized $\Phi_{\mathrm{ST}}$ ) and geographic distance after FDR correction for multiple testing.

\section{Wind stress/upwelling}

Cumulative yearly wind stress during 2001 to 2008 ranged from -1.725 to $-5.179 \mathrm{~N} \mathrm{~m}^{-2}$ (more negative numbers indicate stronger accumulated southward, upwelling-favorable wind stress; Figs. 2 $\& 3$ ). The average wind stress (calculated by dividing cumulative wind stress by the number of days of upwelling-favorable conditions) ranged from -0.0141 to $-0.0267 \mathrm{~N} \mathrm{~m}^{-2}$ with an overall mean of

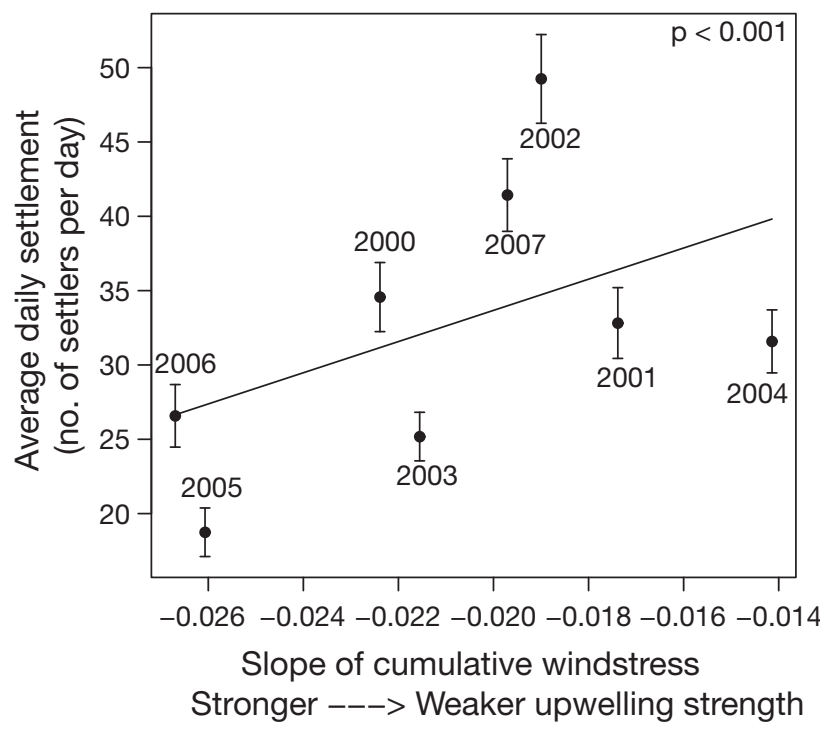

Fig. 2. Balanus glandula. Average daily settlement for each year as compared to the average cumulative wind stress for that same year. Data are mean $\pm 1 \mathrm{SE}$. Settlement was calculated by averaging the number of settlers counted on the plates across the number of days plates were deployed. p-value was calculated using a Kendall's Tau test of positive correlation between daily settlement and average cumulative wind stress 


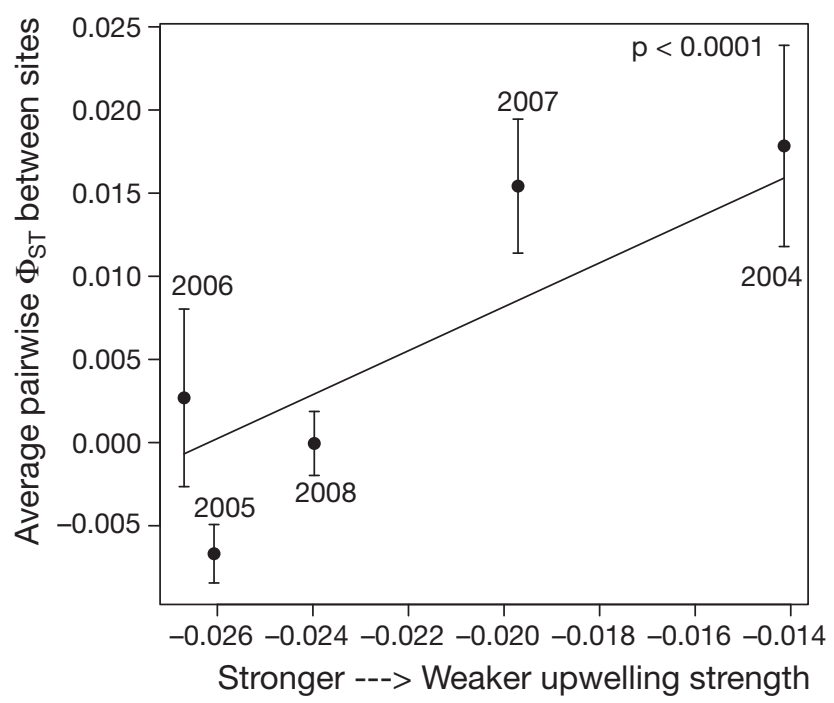

Fig. 3. Balanus glandula. Changes in average pairwise $\Phi_{\mathrm{ST}}$ between populations for each year as compared to the average cumulative wind stress for that same year. Pairwise $\Phi_{\text {ST }}$ values were calculated by taking the average of all pairwise comparisons between populations for that particular year. Data are mean $\pm 1 \mathrm{SE}$. Note that the more negative the value of cumulative wind stress is, the stronger the upwelling strength for that particular year becomes. $p$-value calculated using a Kendall's Tau test of positive correlation between average $\Phi_{\mathrm{ST}}$ and average cumulative wind stress

$-0.0211 \pm 0.00436 \mathrm{~N} \mathrm{~m}^{-2}$. Higher pairwise $\Phi_{\mathrm{ST}}$ values were observed in years with lower cumulative wind stress and weaker predicted degrees of upwelling (Fig. 3). Across years, average pairwise $\Phi_{\mathrm{ST}}$ between populations was positively correlated with the cumulative wind stress (Kendall's Tau, p =0.002; Fig. 3).

\section{Recruitment/settlement}

Mean daily settlement per $100 \mathrm{~cm}^{2}$ across all sites and all years was $46.46 \pm 51.59$. Seal Rock (SR) showed the highest settlement across years (119.55 settlers $100 \mathrm{~cm}^{-2}$ ), while Cape Blanco (CB) had the least (15.52 settlers $100 \mathrm{~cm}^{-2}$ ). Average daily settlement was higher in years with lower cumulative wind stress, and presumably weaker degrees of upwelling (Fig. 2), a trend consistent with previous findings (Roughgarden et al. 1988). Average daily settlement was positively correlated with the average cumulative wind stress ( $p<0.001$; Fig. 2), suggesting an influence of nearshore oceanography on the recruitment dynamics of Balanus glandula. The correlation between population $\Phi_{\mathrm{ST}}$ and average daily settlement was negative but non-significant, but our statistical power to detect a pattern was low (data not shown; $\mathrm{n}=4$ ).

\section{DISCUSSION}

We examined the spatial and temporal genetic structure of the intertidal barnacle Balanus glandula along a $300 \mathrm{~km}$ stretch of the Oregon coastline. The increased temporal resolution of sampling in this study revealed significant shifts in genetic composition among year classes. This temporal variability in population structure was correlated with changes in the strength of oceanographic upwelling among years, indicating a possible influence of upwelling on the genetic composition of the yearly recruitment class.

\section{Oceanography and genetic changes over time}

Our results suggest a link between the composition of the larval pool of Balanus glandula and coastal upwelling, with higher levels of variation among populations during years in which upwelling currents were weakest (Fig. 4). A considerable amount of research has explored how patterns of larval transport, delivery, and recruitment strength are related to the flow dynamics associated with coastal upwelling. A number of studies have observed decreases in larval settlement and abundance during upwelling-favorable conditions and increased settlement and abundance during upwelling relaxation events (e.g. Roughgarden et al. 1988, Alexander \& Roughgarden 1996, Connolly et al. 2001, Ma \& Grassle 2004, Dudas et al. 2009). Similarly, we observed an increase in average daily settlement in years with weaker overall upwelling (Fig. 2), suggesting that in these years, larvae were found closer to shore and fewer were lost to offshore predators, starvation, and currents.

Decreases in offshore transport, reduced intensity of alongshore coastal upwelling jets, lower flow separation (Castelao \& Barth 2006), and slower meander and eddy formation during periods of weaker upwelling are all also consistent with the observation of higher genetic population structure in years with lower cumulative wind stress and weaker average upwelling. The 2 years that exhibited significant population structure, 2004 and 2007, were also the 2 years with the weakest cumulative wind stress.

Under weak upwelling conditions, larvae from local parents might remain in 'packets,' creating a slight increase in population structure due to genetic heterogeneity among 'packets' of larvae settling at the different sampling locations (Fig. 4). In contrast, if larvae are subject to greater offshore and alongshore currents, increased flow separation, and more meanders and eddies in years with stronger up- 
A

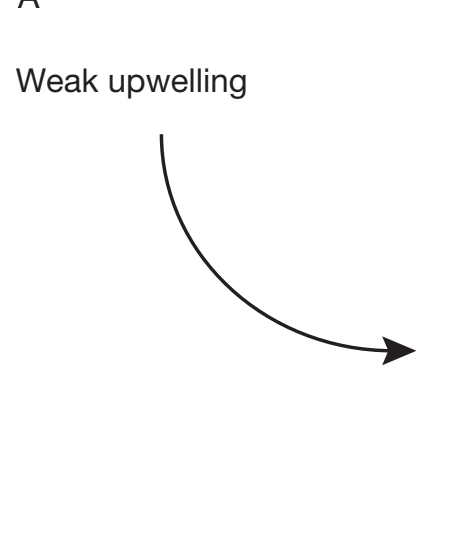

B

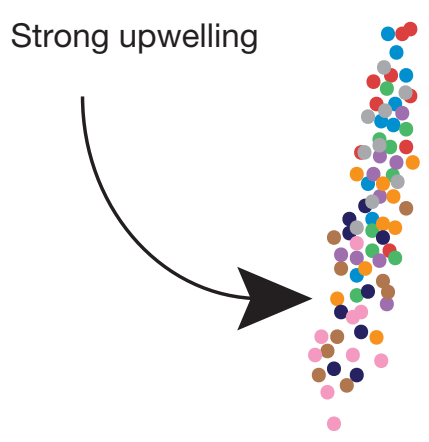

Dispersal

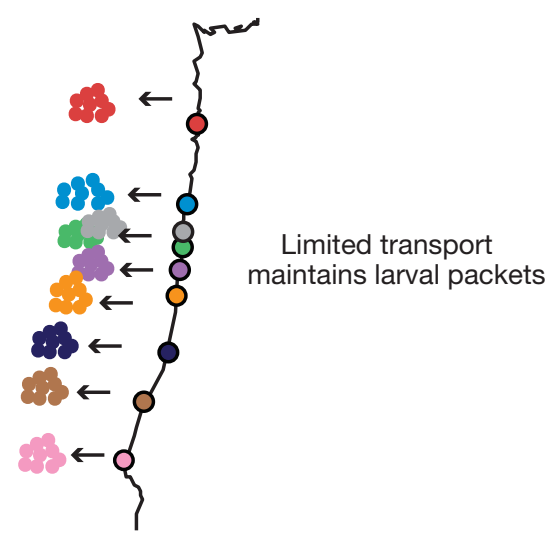

Recruitment

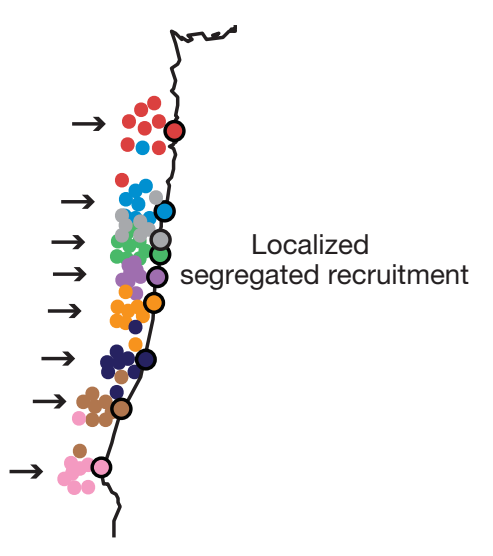

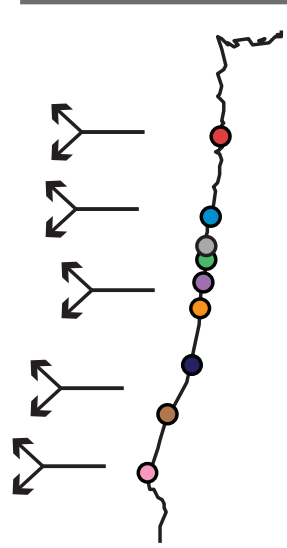

Strong transport disrupts packets

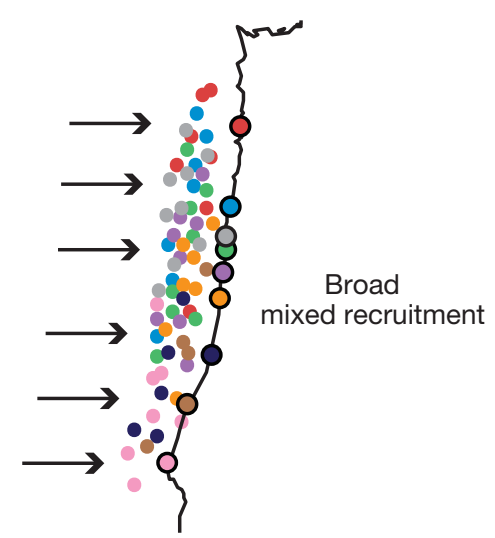

Fig. 4. Balanus glandula. Graphical representation of the hypothetical relationship between upwelling strength, transport, and level of mixing of larval dispersal 'packets.' (A) Conditions under weaker upwelling illustrating reduced transport and retention of segregation among larval 'packets' throughout the dispersal and recruitment phases. (B) Conditions under strong upwelling with greater transport levels, promoting disruption and mixing of larval 'packets,' which results in a more homogenized pool of recruits in years with stronger upwelling conditions. Large circles represent population locations coded by color with smaller circles representing hypothetical larval offspring

welling, this would likely promote increased homogenization over larger spatial scales and weaker population substructure in the recruits from those particular years (Fig. 4). Recent oceanographic modeling along the southern California coastline has described the stochastic nature of the dispersal trajectory of larval 'packets,' and has shown how local current patterns can contribute to high variability in the connectivity among populations over short $(<1 \mathrm{yr})$ time scales (Siegel et al. 2008). Additional work is needed along the Oregon coast to ascertain whether this model applies in a similar fashion. Also, we observed genetic homogeneity among the adult populations sampled in this study; thus, even if larvae were to cluster together in localized 'packets,' patterns among adults do not necessarily predict genetic differentiation among local groups of larvae.

\section{Influences on larval production}

Previous work on Balanus glandula along the Oregon coast has identified a strong influence of nearshore oceanic conditions on barnacle reproductive output, with 120 times greater mean larval production in a 'hotspot' region of high primary productivity compared to sites $65 \mathrm{~km}$ away with much lower levels of primary productivity (Leslie et al. 2005). These areas of high productivity are also areas of locally high and variable upwelling (Tapia et al. 2009).

In years of high upwelling, elevated larval production might be mixed among adjacent populations, generating broader regions of genetic homogeneity. In years of low upwelling, high numbers of local larvae might remain close to shore and fail to be transported widely throughout the coast. Our single-locus 
data do not allow us to conclusively support or reject the possibility of reproductive hotspots shaping the composition of the larval pool; future research is therefore needed to assess the relationship between differences in primary production, reproductive output, and the resulting effects on barnacle settlers. Efforts could focus on intensive sampling along a productivity gradient to identify the potential sources of recruiting larvae in years with larger versus smaller differences in primary productivity.

\section{Spatial variation and selection}

Some type of pre- or post-settlement selective mechanism could also cause the temporal shifts in genetic composition of the year classes of barnacles in this study. Coastal areas typically show spatial differences in a number of environmental variables, including local temperature, nutrient concentrations, and primary productivity signatures. Recent studies have found complicated patterns of thermal anomalies and thermal stress in the Oregon intertidal (e.g. Helmuth et al. 2002, Sagarin \& Somero 2006) that correlate with strong adaptive differences in upper thermal tolerance limits of intertidal snails (Kuo \& Sanford 2009). Selection has also been invoked previously in barnacles as a potential explanation for a strong genetic cline observed in Balanus glandula populations across California (Sotka et al. 2004, Galindo et al. 2010), microgeographic heterogeneity between different tidal zones (Hedgecock 1986), as well as in populations of the related Semibalanus balanoides to explain genetic changes in response to microhabitat differences in temperature (Schmidt \& Rand 1999). If selection were responsible for the temporal shifts in genetic structure observed in the current study, then this selection would need to increase in years of low upwelling. This may be possible if low upwelling favors on-shore local water retention, and if these local water masses exert selective pressure on adults during spawning, on larval stages, or on settling cyprids. In fact, Galindo et al. (2010) posited a combination of strong coastal retention and selection as a possible explanation for barnacle genetic patterns in California. The locations sampled in the current study are subject to differing degrees of upwelling intensity (Tapia et al. 2009), which could produce a gradient in selection pressure among sites. However, one might assume environmental differences among sites to be greatest in years with higher upwelling intensity (see Fig. 1 in Sanford \& Kelly 2011), which does not readily explain the increased genetic heterogeneity among locations in years with weaker upwelling.

It is notable that our sampling methods were not designed to investigate micro-environmental selection across intertidal zones (e.g. Hedgecock 1986), as all settlement plates were placed at approximately the same tidal height within a given location. Past investigations have failed to find depth-related variation in barnacle genetics at the COI locus (e.g. Wares \& Cunningham 2005, Galindo et al. 2010). Similarly, a preliminary comparison of gene frequencies in early and later settlement stages showed no significant differences (Galindo et al. 2010). Based on previous research (e.g. Hedgecock 1986, Schmidt \& Rand 1999, Sotka et al. 2004), it is likely that selective forces are shaping Balanus glandula populations, yet in a complicated manner counterintuitive to what we might expect (i.e. potentially greater amounts of selection in years with weaker upwelling). Additional, detailed profiling of environmental conditions is needed to identify potential differential selection pressures among local water masses in weaker upwelling years.

\section{Popular sweepstakes for barnacles}

Another commonly invoked mechanism to explain temporal genetic variation as seen in the current study is the 'reproductive sweepstakes' hypothesis (Hedgecock 1994a), which posits that temporal genetic patchiness is a consequence of high variance in reproductive success among individuals and families. The main hypothesis of reproductive sweepstakes is that a minority of individuals produces enough offspring to dominate a settlement cohort, thereby resulting in a reduction of genetic diversity in the offspring and changes in the composition of the recruitment pool over time. In the case of Balanus glandula along the Oregon coastline, we see increased genetic structure during years of decreased settlement, possibly indicating a link between the size of the recruit pool and genetic variability. However, the lack of an observed reduction in genetic diversity in the present study leads us to conclude that, sensu Flowers et al. (2002), this particular sweepstakes may have many winners. B. glandula is among the most common intertidal barnacles along the west coasts of Canada and the USA (Newman \& Abbott 1980). Given the average daily settlement observed in the present study (15 to 120 settlers $100 \mathrm{~cm}^{-2} \mathrm{~d}^{-1}$; mean $=46.5$; over $\sim 5$ mo of measurement $=\sim 697500$ successful recruits $\mathrm{m}^{-2} \mathrm{yr}^{-1}$ ) and a maximum reproductive output of 180000 nauplii female ${ }^{-1}$ season $^{-1}$, at 
least 130 females with a recruitment success greater than $3 \%$ would be required to supply the number of successfully recruiting larvae per $\mathrm{m}^{2}$ of habitat. This rough calculation suggests that genetic drift could shape changes in the genetic makeup of the larval pool from year to year. However, the lack of a detectable reduction in genetic diversity between adults and recruits and the lack of detectable spatial genetic structure in adult populations indicate that enough adults are successfully reproducing to maintain diversity across generations.

Other possible mechanisms that might be responsible for the temporal variability seen in the present study could be an increase in reproductive variance caused by hermaphroditism, extended sibships, and kin-aggregation, as proposed by Veliz et al. (2006) for the acorn barnacle Semibalanus balanoides. Future studies using nuclear markers capable of resolving these close relationships and how they change in relation to local oceanographic forces might be better able to elucidate whether a clear signal of increased local retention/recruitment is seen in years with lower upwelling intensity.

\section{CONCLUSIONS}

Despite continued maintenance of high abundances and levels of genetic diversity in Oregon, these Balanus glandula populations exhibited significant temporal shifts in the genetic makeup of the recruitment year classes. The genetic composition of individual year classes varied between years, and patterns of population subdivision of recruits were observed in multiple years despite no detectable spatial genetic structuring in adults. We hypothesize that the increased population structure during years with weaker upwelling strength is most parsimonious with limited along-shore mixing and localized association of related larvae in 'clumps' or 'packets.' The specific mechanism causing the differentiation of these 'packets' remains unknown, as the potential influences of selection or temporal genetic drift alone do not adequately explain the observed differences among recruitment cohorts. These findings are in line with those of a recent study of the intertidal anomuran crab Petrolisthes cinctipes (Toonen \& Grosberg in press), which found no single mechanistic explanation for temporally variable genetic heterogeneity, but rather evidence for a combination of multiple forces, including pre- or post-settlement natural selection, localized recruitment, and variation in larval dispersal and reproductive success. The data presented here suggest that coastal upwelling dynamics may play a role beyond driving larval abundances, and could serve to shape the spatial distribution of genetic material within yearly classes of recruits via a combinatorial influence on larval delivery, reproductive output, and environmental characteristics of local water masses. These data shed new light on the influence of near-shore oceanography on the recruitment dynamics of an intertidal model organism, and are among the first to link variability in coastal upwelling with the genetic composition of intertidal recruits.

Acknowledgements. This research is the culmination of a long line of field and laboratory researchers without whom this project would not have been possible; thanks to K. R. Barr, V. B. Searles, E. Jacobs-Palmer, K. Deiner, and J. C. Lee for field and lab support; the Menge and Lubchenco lab members for logistical support and settlement data; $\mathrm{S}$. Pierce for the cumulative wind-stress index; and the Palumbi lab journal club and 3 anonymous reviewers for valuable comments. GenBank accession numbers for all sequences used in this study can be found in Table 2. This work was supported by the Andrew W. Mellon Foundation, the Partnership for the Interdisciplinary Study of Coastal Oceans (PISCO) of The David and Lucile Packard Foundation, and the Gordon and Betty Moore Foundation.

\section{LITERATURE CITED}

Alexander SE, Roughgarden J (1996) Larval transport and population dynamics of intertidal barnacles: a coupled benthic/oceanic model. Ecol Monogr 66:259-275

$>$ Barth JA, Menge BA, Lubchenco J, Chan F and others (2007) Delayed upwelling alters nearshore coastal ocean ecosystems in the northern California current. Proc Natl Acad Sci USA 104:3719-3724

Bohonak AJ (1999) Dispersal, gene flow, and population structure. Q Rev Biol 74:21-45

Broitman BR, Blanchette CA, Menge BA, Lubchenco J and others (2008) Spatial and temporal patterns of invertebrate recruitment along the west coast of the United States. Ecol Monogr 78:403-421

> Brown SK, Roughgarden J (1985) Growth, morphology, and laboratory culture of larvae of Balanus glandula (Cirripedia, Thoracica). J Crustac Biol 5:574-590

> Burford MO, Larson RJ (2007) Genetic heterogeneity in a single year-class from a panmictic population of adult blue rockfish (Sebastes mystinus). Mar Biol 151:451-465

Calderón I, Palacin C, Turon X (2009) Microsatellite markers reveal shallow genetic differentiation between cohorts of the common sea urchin Paracentrotus lividus (Lamarck) in northwest Mediterranean. Mol Ecol 18:3036-3049

Castelao RM, Barth JA (2006) The relative importance of wind strength and along-shelf bathymetric variations on the separation of a coastal upwelling jet. J Phys Oceanogr 36:412-425

Chapman RW, Ball AO, Mash LR (2002) Spatial homogeneity and temporal heterogeneity of red drum (Sciaenops ocellatus) microsatellites: effective population sizes and management implications. Mar Biotechnol 4:589-603 
Christie MR, Johnson DW, Stallings CD, Hixon MA (2010) Self-recruitment and sweepstakes reproduction amid extensive gene flow in a coral-reef fish. Mol Ecol 19: 1042-1057

> Colgan DJ (1981) Spatial and temporal variation in the genotypic frequencies of the mussel Brachidontes rostratus. Heredity 46:197-208

> Connolly SR, Menge BA, Roughgarden J (2001) A latitudinal gradient in recruitment of intertidal invertebrates in the northeast Pacific Ocean. Ecology 82:1799-1813

Coyne JA, Orr HA (2004) Speciation, Vol 1. Sinauer Associates, Sunderland, MA

> Dannewitz J, Maes GE, Johansson L, Wickstrom H, Volckaert FAM, Jarvi T (2005) Panmixia in the European eel: a matter of time. Proc Biol Sci 272:1129-1137

- David P, Perdieu MA, Pernot AF, Jarne P (1997) Finegrained spatial and temporal population genetic structure in the marine bivalve Spisula ovalis. Evolution 51: 1318-1322

> De Wolf H, Backeljau T, Verhagen R (1998) Spatio-temporal genetic structure and gene flow between two distinct shell morphs of the planktonic developing periwinkle Littorina striata (Mollusca: Prosobranchia). Mar Ecol Prog Ser 163:155-163

> Diaz-Jaimes P, Uribe-Alcocer M, Ortega-Garcia S, Durand JD (2006) Spatial and temporal mitochondrial DNA genetic homogeneity of dolphinfish populations (Coryphaena hippurus) in the eastern central Pacific. Fish Res 80:333-338

Dobzhansky T (1982) Genetics and the origin of species. Columbia University Press, New York, NY

- Dudas SE, Grantham BA, Kirincich AR, Menge BA, Lubchenco J, Barth JA (2009) Current reversals as determinants of intertidal recruitment on the central Oregon coast. ICES J Mar Sci 66:396-407

- Escribano R, Hidalgo P (2000) Spatial distribution of copepods in the north of the Humboldt Current region off Chile during coastal upwelling. J Mar Biol Assoc UK 80: 283-290

> Farrell TM, Bracher D, Roughgarden J (1991) Cross-shelf transport causes recruitment to intertidal populations in central California. Limnol Oceanogr 36:279-288

> Flowers JM, Schroeter SC, Burton RS (2002) The recruitment sweepstakes has many winners: genetic evidence from the sea urchin Strongylocentrotus purpuratus. Evolution 56:1445-1453

Galindo HM, Pfeiffer-Herbert AS, McManus MA, Chao YI, Chai FEI, Palumbi SR (2010) Seascape genetics along a steep cline: using genetic patterns to test predictions of marine larval dispersal. Mol Ecol 19:3692-3707

Gilg MR, Hilbish TJ (2003) Spatio-temporal patterns in the genetic structure of recently settled blue mussels ( $\mathrm{My}$ tilus spp.) across a hybrid zone. Mar Biol 143:679-690

Gold JR, Richardson LR, Turner TF (1999) Temporal stability and spatial divergence of mitochondrial DNA haplotype frequencies in red drum (Sciaenops ocellatus) from coastal regions of the western Atlantic Ocean and Gulf of Mexico. Mar Biol 133:593-602

Hedgecock D (1982) Genetic consequences of larval retention: theoretical and methodological aspects. In: Kennedy VS (ed) Estuarine comparisons. Academic Press, New York, NY, p 553-568

Hedgecock D (1986) Is gene flow from pelagic larval dispersal important in the adaptation and evolution of marine invertebrates? Bull Mar Sci 39:550-564
Hedgecock D (1994a) Does variance in reproductive success limit effective population sizes of marine organisms? In: Beaumont A (ed) Genetics and evolution of aquatic organisms. Chapman \& Hall, London, p 122-134

Hedgecock D (1994b) Temporal and spatial genetic structure of marine animal populations in the California Current. Calif Coop Ocean Fish Invest Rep 35:73-81

Hedgecock D, Launey S, Pudovkin A, Naciri Y, Lapègue S, Bonhomme F (2007) Small effective number of parents $(\mathrm{Nb})$ inferred for a naturally spawned cohort of juvenile European flat oysters Ostrea edulis. Mar Biol 150: 1173-1182

> Helmuth B, Harley CDG, Halpin PM, O'Donnell M, Hofmann GE, Blanchette CA (2002) Climate change and latitudinal patterns of intertidal thermal stress. Science 298: 1015-1017

Jensen JL, Bohonak AJ, Kelley ST (2005) Isolation by distance, web service. BMC Genet 6:13

> Johnson MS, Black R (1982) Chaotic genetic patchiness in an inter-tidal limpet, Siphonaria sp. Mar Biol 70:157-164

Johnson MS, Black R (1984) Pattern beneath the chaos - the effect of recruitment on genetic patchiness in an intertidal limpet. Evolution 38:1371-1383

Johnson MS, Wernham J (1999) Temporal variation of recruits as a basis of ephemeral genetic heterogeneity in the western rock lobster Panulirus cygnus. Mar Biol 135:133-139

> Kuo ESL, Sanford E (2009) Geographic variation in the upper thermal limits of an intertidal snail: implications for climate envelope models. Mar Ecol Prog Ser 388: 137-146

Lagos NA, Navarrete SA, Véliz F, Masuero A, Castilla JC (2005) Meso-scale spatial variation in settlement and recruitment of intertidal barnacles along the coast of central Chile. Mar Ecol Prog Ser 290:165-178

Lambert WJ, Todd CD, Thorpe JP (2003) Genetic population structure of two intertidal nudibranch molluscs with contrasting larval types: temporal variation and transplant experiments. Mar Biol 142:461-471

Lenfant P, Planes S (2002) Temporal genetic changes between cohorts in a natural population of a marine fish, Diplodus sargus. Biol J Linn Soc 76:9-20

- Leslie HM, Breck EN, Chan F, Lubchenco J, Menge BA (2005) Barnacle reproductive hotspots linked to nearshore ocean conditions. Proc Natl Acad Sci USA 102: 10534-10539

> Lessios HA, Weinberg JR, Starczak VR (1994) Temporal variation in populations of the marine isopod Excirolana: How stable are gene-frequencies and morphology? Evolution 48:549-563

> Li G, Hedgecock D (1998) Genetic heterogeneity, detected by PCR-SSCP, among samples of larval Pacific oysters (Crassostrea gigas) supports the hypothesis of large variance in reproductive success. Can J Fish Aquat Sci 55: 1025-1033

> Liu JX, Ely B (2009) Sibship reconstruction demonstrates the extremely low effective population size of striped bass Morone saxatilis in the Santee-Cooper system, South Carolina, USA. Mol Ecol 18:4112-4120

Lundy CJ, Rico C, Hewitt GM (2000) Temporal and spatial genetic variation in spawning grounds of European hake (Merluccius merluccius) in the Bay of Biscay. Mol Ecol 9: 2067-2079

> Ma HG, Grassle JP (2004) Invertebrate larval availability during summer upwelling and downwelling on the inner continental shelf off New Jersey. J Mar Res 62:837-865 
McPherson AA, Stephenson RL, Taggart CT (2003) Genetically different Atlantic herring Clupea harengus spawning waves. Mar Ecol Prog Ser 247:303-309

Menge BA (2000) Recruitment vs. postrecruitment processes as determinants of barnacle population abundance. Ecol Monogr 70:265-288

Menge BA, Daley BA, Lubchenco J, Sanford E and others (1999) Top-down and bottom-up regulation of New Zealand rocky intertidal communities. Ecol Monogr 69: 297-330

Menge BA, Foley MM, Pamplin J, Murphy G, Pennington C (2010) Supply-side ecology, barnacle recruitment, and rocky intertidal community dynamics: Do settlement surface and limpet disturbance matter? J Exp Mar Biol Ecol 392:160-175

Moberg PE, Burton RS (2000) Genetic heterogeneity among adult and recruit red sea urchins, Strongylocentrotus franciscanus. Mar Biol 136:773-784

Morgan SG, Fisher JL (2010) Larval behavior regulates nearshore retention and offshore migration in an upwelling shadow and along the open coast. Mar Ecol Prog Ser 404:109-126

> Morgan SG, Fisher JL, Mace AJ (2009a) Larval recruitment in a region of strong, persistent upwelling and recruitment limitation. Mar Ecol Prog Ser 394:79-99

- Morgan SG, Fisher JL, Miller SH, McAfee ST, Largier JL (2009b) Nearshore larval retention in a region of strong upwelling and recruitment limitation. Ecology 90: 3489-3502

Newman WA, Abbott DP (1980) Cirripedia: the barnacles. In: Morris RH, Abbott DP, Haderlie EC (eds) Intertidal invertebrates of California. Stanford University Press, Stanford, CA, p 504-535

Palumbi SR (2003) Population genetics, demographic connectivity, and the design of marine reserves. Ecol Appl 13:146-158

Pierce SD, Barth JA (2009) Cumulative wind stress: a data product for Oregon upwelling-related research. College of Oceanic \& Atmospheric Sciences, Oregon State University, Corvallis, OR

> Pierce SD, Barth JA, Thomas RE, Fleischer GW (2006) Anomalously warm July 2005 in the northern California Current: historical context and the significance of cumulative wind stress. Geophys Res Lett 33:L22S04, doi:10. 1029/2006GL027149

> Planes S, Lenfant P (2002) Temporal change in the genetic structure between and within cohorts of a marine fish, Diplodus sargus, induced by a large variance in individual reproductive success. Mol Ecol 11:1515-1524

Poulin E, Palma AT, Leiva G, Narvaez D, Pacheco R, Navarrete SA, Castilla JC (2002) Avoiding offshore transport of competent larvae during upwelling events: the case of the gastropod Concholepas concholepas in central Chile. Limnol Oceanogr 47:1248-1255

Roughgarden J, Gaines S, Possingham H (1988) Recruitment dynamics in complex life cycles. Science 241:1460-1466

Sagarin RD, Somero GN (2006) Complex patterns of expression of heat-shock protein 70 across the southern biogeographical ranges of the intertidal mussel Mytilus californianus and snail Nucella ostrina. J Biogeogr 33: 622-630

Sanford E, Kelly M (2011) Local adaptation in marine

Editorial responsibility: Karen Miller,

Hobart, Tasmania, Australia invertebrates. Annu Rev Mar Sci 3:509-535

Schmidt PS, Rand DM (1999) Intertidal microhabitat and selection at Mpi: interlocus contrasts in the northern acorn barnacle, Semibalanus balanoides. Evolution 53: 135-146

Schneider S, Roessli D, Excoffier L (2000) Arlequin: a software for population genetics data analysis. Genetics and Biometry Lab, Department of of Anthropology, University of Geneva

> Shanks AL (2009) Pelagic larval duration and dispersal distance revisited. Biol Bull (Woods Hole) 216:373-385

Shanks AL, Brink L (2005) Upwelling, downwelling, and cross-shelf transport of bivalve larvae: test of a hypothesis. Mar Ecol Prog Ser 302:1-12

- Shanks AL, Pfister CA (2009) Annual recruitment of three species of tide-pool fishes is driven by variation in springtime coastal hydrodynamics. Limnol Oceanogr 54: 1481-1487

Shanks AL, Shearman RK (2009) Paradigm lost? Cross-shelf distributions of intertidal invertebrate larvae are unaffected by upwelling or downwelling. Mar Ecol Prog Ser 385:189-204

Siegel DA, Mitarai S, Costello CJ, Gaines SD, Kendall BE, Warner RR, Winters KB (2008) The stochastic nature of larval connectivity among nearshore marine populations. Proc Natl Acad Sci USA 105:8974-8979

> Sotka EE, Wares JP, Barth JA, Grosberg RK, Palumbi SR (2004) Strong genetic clines and geographical variation in gene flow in the rocky intertidal barnacle Balanus glandula. Mol Ecol 13:2143-2156

Strimmer K (2008) A unified approach to false discovery rate estimation. BMC Bioinformatics 9:303

- Tapia FJ, Navarrete SA, Castillo M, Menge BA and others (2009) Thermal indices of upwelling effects on innershelf habitats. Prog Oceanogr 83:278-287

Toonen RJ, Grosberg R (in press) Causes of chaos: spatial and temporal genetic heterogeneity in the intertidal anomuran crab Petrolisthes cinctipes. In: Koenemann C, Held C, Shubart C (eds) Phylogeography and population genetics in Crustacea. CRC Press Crustacean Issues Series. CRC Press, Boca Raton, FL

Veliz D, Duchesne P, Bourget E, Bernatchez L (2006) Genetic evidence for kin aggregation in the intertidal acorn barnacle (Semibalanus balanoides). Mol Ecol 15:4193-4202

> Wares JP, Cunningham CW (2005) Diversification before the most recent glaciation in Balanus glandula. Biol Bull (Woods Hole) 208:60-68

> Wares JP, Gaines SD, Cunningham CW (2001) A comparative study of asymmetric migration events across a marine biogeographic boundary. Evolution 55:295-306

Watterson GA (1975) On the number of segregating sites in genetical models without recombination. Theor Popul Biol 7:256-276

Weir B, Cockerham C (1984) Estimating F-statistics for the analysis of population structure. Evolution 38:1358-1370

> Weissberger EJ, Grassle JP (2003) Settlement, first-year growth, and mortality of surfclams, Spisula solidissima. Estuar Coast Shelf Sci 56:669-684

Wing SR, Botsford LW, Largier JL, Morgan LE (1995) Spatial structure of relaxation events and crab settlement in the northern California upwelling system. Mar Ecol Prog Ser 128:199-211

Submitted: June 22, 2010; Accepted: August 9, 2011

Proofs received from author(s): October 14, 2011 